\title{
STUDI ANALISIS DIMENSI DAN STABILITAS TUBUH BENDUNGAN URUGAN BERINGIN SILA
}

\author{
Natalia Yuliana Margaretha \\ Jurusan/Program Studi Teknik Sipil, Fakultas Teknik, Universitas Palangka Raya \\ Jln. Hendrik Timang, Palangka Raya, e-mail: nataliahurek21322@gmail.com \\ I Made Kamiana \\ Jurusan/Program Studi Teknik Sipil, Fakultas Teknik, Universitas Palangka Raya \\ Jln. Hendrik Timang, Palangka Raya, e-mail: kamianamade@eng.upr.ac.id \\ Dwi Anung Nindito \\ Jurusan/Program Studi Teknik Sipil, Fakultas Teknik, Universitas Palangka Raya \\ Jln. Hendrik Timang, Palangka Raya, e-mail: dwi_anungnindito@eng.upr.ac.id
}

\begin{abstract}
Beringin Sila embankment dam is a water reservoir construction that is planned to overcome the imbalance quantity of water available to meet the needs of the community in the Utan District, Sumbawa Regency. Therefore, the analysis of dimensions and stability needs to be carried out to obtain an effective dam construction to collect water and meet dam safety requirements that are influenced by forces acting on the dam. The calculation methods used in determining the dimensional analysis are flooded retesting for 1.000 years and the S.M.B. method. The stability calculation method used is the Cassagrande method to determine the seepage line formation with the terms Qf $<$ Qinflowmax, Forchheimer to draw a seepage flow-net, Bishop to determine the stability of the dam's body slope with the condition $S_{\mathrm{f}}>1,2$. Dimension calculation results in 87 meters high dam, 13 meters wide beam, 800,93 meters long dam, upstream slope 1: 4, downstream slope 1: 3 , horizontal drainage dimensions 2 meters x 240 meters. The results of the analysis of the stability of the dam seepage obtained $11,88 \times 10-3 \mathrm{~m} 3 / \mathrm{sec}<11,88 \mathrm{~m} 3 / \mathrm{sec}$ (safe) The analysis results in the stability of the dam slope at the condition of the after construction slope upstream 4,34 (safe) and slope downstream 2,99 (safe), the dam water level reaches a full elevation of 2,13 (safe), and the condition of the dam rapid drawdown sudden 3,82 (safe). The results of the stability analysis of boiling and piping obtained $6,44 \times 10^{-6} \mathrm{~m} / \mathrm{sec}<0,06 \mathrm{~m} / \mathrm{sec}$ (safe).
\end{abstract}

Keywords: dimension analysis, stability analysis, rock fill dam

\begin{abstract}
Abstrak: Bendungan urugan Beringin Sila merupakan konstruksi penampung air yang direncanakan untuk mengatasi masalah ketidakseimbangan kuantitas air yang tersedia dalam memenuhi kebutuhan masyarakat di Kecamatan Utan, Kabupaten Sumbawa. Oleh karena itu, analisis dimensi dan stabilitas bendungan perlu dilakukan dengan tujuan memperoleh konstruksi bendungan yang efektif untuk menampung air dan memenuhi syarat keamanan bendungan yang dipengaruhi oleh gaya-gaya yang bekerja pada bendungan. Metode perhitungan yang digunakan dalam menentukan analisis dimensi yaitu penelusuran banjir kala ulang 1.000 tahun dan metode S.M.B. Metode perhitungan stabilitas yang digunakan yaitu metode Cassagrande untuk mengetahui formasi garis depresi dengan syarat $\mathrm{Q}_{\mathrm{f}}<\mathrm{Q}_{\text {inflowmaks}}$, Forchheimer untuk menggambar jaringan trayektori, dan Bishop untuk mengetahui stabilitas lereng tubuh bendungan dengan syarat $\mathrm{F}_{\mathrm{k}}>1,2$. Hasil perhitungan dimensi diperoleh tinggi bendungan 87 meter, lebar mercu 13 meter, panjang bendungan 800,93 meter, kemiringan lereng hulu 1:4, kemiringan lereng hilir 1:3, dimensi drainase horisontal 2 meter x 240 meter. Hasil analisis terhadap stabilitas aliran filtrasi bendungan diperoleh $11,88 \times 10^{-3} \mathrm{~m}^{3} / \mathrm{det}<11,88 \mathrm{~m}^{3} / \mathrm{det}$ (aman). Hasil analisis terhadap stabilitas lereng bendungan pada kondisi baru selesai dibangun sisi hulu 4,34 (aman) dan hilir 2,99 (aman), pada kondisi muka air bendungan mencapai elevasi penuh 2,13 (aman), dan pada kondisi bendungan mengalami penurunan air mendadak 3,82 (aman). Hasil analisis stabilitas terhadap boiling dan piping diperoleh $6,44 \times 10^{-6} \mathrm{~m} / \mathrm{det}<0,06 \mathrm{~m} / \operatorname{det}$ (aman).
\end{abstract}

Kata kunci: : analisis dimensi, analisis stabilitas, bendungan urugan 


\section{PENDAHULUAN}

Pembangunan bendungan urugan merupakan salah satu solusi yang dipilih untuk mengatasi ketidakseimbangan kuantitas air yang tersedia untuk memenuhi tingginya tingkat kebutuhan air masyarakat suatu daerah, mengingat salah satu fungsi bendungan adalah sebagai konstruksi penampung air.

Tahapan pembangunan bendungan secara umum terdiri atas tahapan studi, penyelidikan, perencanaan, pelaksanaan konstruksi, serta operasi dan pemeliharaan (Soedibyo, 2003). Tahapan perencanaan bendungan urugan merupakan salah satu proses penting dalam tahapan pembangunan bendungan karena tahapan ini bertujuan untuk menganalisis dan menentukan kapasitas kemampuan bendungan yang direncanakan sebagai konstruksi penampung air.

Untuk mendapatkan konstruksi bendungan urugan yang efektif menampung kebutuhan air rencana dan memenuhi syarat keamanan bendungan, maka perlu diketahui bagaimana analisis dimensi dan analisis stabilitas tubuh bendungan urugan agar tujuan perencanaan bendungan dapat terpenuhi. Adapun jenis bendungan urugan yang dianalisis adalah bendungan urugan batu dengan inti vertikal.

\section{TINJAUAN PUSTAKA}

\section{Dimensi Bendungan Urugan}

Dalam perhitungan analisis dimensi tubuh bendungan urugan terdapat beberapa faktor yang mempengaruhi antara lain kebutuhan air, volume tampungan rencana, dan penelusuran banjir. Berdasarkan pertimbangan terhadap faktor tersebut maka dimensi tubuh bendungan urugan dapat diketahui dengan menentukan tinggi jagaan, tinggi bendungan, lebar puncak bendungan, panjang bendungan, kemiringan lereng hulu dan kemiringan lereng hilir bendungan, pelindung lereng bendungan, pondasi bendungan, serta drainase bendungan .

Rumus, syarat, dan metode yang digunakan dalam analisis dimensi tubuh bendungan urugan adalah :

1. Kebutuhan air dan tampungan bendungan

$$
\mathrm{Vol}_{\cdot T N}=\mathrm{Vol}_{\cdot T H}+\mathrm{Vol}_{\cdot T M}
$$

dengan Vol. TN $=$ volume tampungan normal $\left(\mathrm{m}^{3}\right)$, Vol.тн $=$ volume tampungan hidup $\left(\mathrm{m}^{3}\right)$, Vol.TM $=$ volume tampungan mati $\left(\mathrm{m}^{3}\right)$ (Soedibyo, 2003).

2. Penelusuran banjir

$\frac{I_{1}+I_{2}}{2}+\psi_{1}=\varphi_{2}$

dengan $\mathrm{I}_{1}$ dan $\mathrm{I}_{2}=$ debit inflow $\left(\mathrm{m}^{3} / \mathrm{det}\right), \psi_{1}$ $=$ tampungan ke- $\mathrm{i}$ per satuan waktu dikurangi debit outflow ke-i ( $\left.\mathrm{m}^{3} / \mathrm{det}\right), \varphi_{2}=$ tampungan ke-n per satuan waktu ditambah debit outflow ke-n ( $\left.\mathrm{m}^{3} / \mathrm{det}\right)$ (Soemarno, 1987). Penelusuran banjir menggunakan metode penelusuran banjir lewat waduk dengan kala ulang 1.000 tahun.

3. Dimensi tubuh bendungan

a. Tinggi jagaan $\left(\mathrm{H}_{\mathrm{f}}\right)$

$$
\begin{aligned}
& H_{f}=\Delta H+h_{w}+h_{a}+h_{i} \\
& H_{f}=\Delta H+\frac{h_{e}}{2}+h_{a}+h_{i} \\
& H_{f}=h_{w}+\frac{h_{e}}{2}+h_{a}+h_{i}
\end{aligned}
$$

dengan $\mathrm{H}_{\mathrm{f}}=$ tinggi jagaan $(\mathrm{m}), \mathrm{h}_{\mathrm{w}}=$ tinggi ombak akibat tiupan angin $(\mathrm{m})$ (ditentukan menggunakan metode S.M.B), $h_{e}=$ tinggi ombak akibat gempa $(\mathrm{m}), \mathrm{h}_{\mathrm{a}}=$ tinggi kemungkinan kenaikan permukaan air waduk apabila terjadi kemacetan-kemacetan pada pintu bangunan pelimpah $(\mathrm{m}), \mathrm{h}_{\mathrm{i}}=$ tinggi tambahan yang didasarkan pada tingkat urgensi dari waduk (m) (Sosrodarsono dan Takeda, 2002). Dari ketiga persamaan tersebut dipilih persamaan dengan hasil terbesar.

b. Tinggi bendungan $(\mathrm{H})$

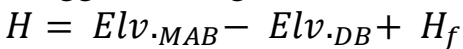

dengan $\mathrm{H}=$ tinggi bendungan $(\mathrm{m})$, Elv.мAB = elevasi muka air banjir (m), Elv.DB = elevasi dasar bendungan $(\mathrm{m})$, dan $\mathrm{H}_{\mathrm{f}}=$ tinggi jagaan $(\mathrm{m})$ (Sosrodarsono dan Takeda, 2002).

c. Lebar mercu (b)

$b=\left(3,6 \times H^{1 / 3}\right)-3,0$

dengan $\mathrm{b}=$ lebar mercu $(\mathrm{m})$ dan $\mathrm{H}=$ tinggi bendungan $(\mathrm{m})$ (Sosrodarsono dan Takeda, 2002).

d. Panjang bendungan (L)

Panjang bendungan ditentukan berdasarkan keadaan topografi lokasi bendungan (Sosrodarsono dan Takeda, 2002).

e. Kemiringan lereng hulu dan kemiringan lereng hilir 
1.) Kemiringan lereng hulu $\left(\mathrm{F}_{\mathrm{su}}\right)$ $F_{\text {su }}=\frac{m-k \times j^{\prime}}{1+k \times j^{\prime} \times m} \times \tan \phi>1,1(8)$ dengan $\mathrm{F}_{\mathrm{su}}=$ angka keamanan kemiringan lereng hulu, $\mathrm{m}=$ kemiringan lereng hulu, $\mathrm{k}=$ koefisien gempa, $\phi=$ sudut geser dalam bahan timbunan $\left({ }^{\circ}\right)$, dan $\mathrm{j}^{\prime}=$ berat volume dalam air $\left(\right.$ ton $/ \mathrm{m}^{3}$ ) (Sosrodarsono dan Takeda, 2002).

2.) Kemiringan lereng hilir $\left(\mathrm{F}_{\mathrm{sd}}\right)$

$F_{s d}=\frac{n-k}{1+k \times n} x \tan \phi>1,1$

dengan $\mathrm{F}_{\mathrm{sd}}=$ angka keamanan kemiringan lereng hilir, $\mathrm{n}=$ kemiringan lereng hilir, $\mathrm{k}=$ koefisien gempa, dan $\phi=$ sudut geser dalam bahan timbunan $\left(^{\circ}\right)$ (Sosrodarsono dan Takeda, 2002).

f. Pelindung lereng

Pelindung lereng hilir dan hulu bendungan urugan dapat digunakan hamparan batu pelindung atau riprap (Sosrodarsono dan Takeda, 2002).

g. Pondasi bendungan

Pondasi bendungan urugan yang direncanakan dapat ditentukan berdasarkan kondisi geologi lokasi as bendungan (Anonim, 2003).

h. Drainase bendungan

Drainase bendungan urugan yang dipilih adalah tipe drainase horizontal.

\section{Stabilitas Bendungan Urugan}

Stabilitas terhadap konstruksi tubuh bendungan urugan bertujuan untuk menentukan dimensi bendungan urugan yang tepat sehingga mampu menahan beban-beban dan gaya-gaya yang bekerja pada tubuh bendungan selama bendungan (Soedibyo, 2003). Analisis terhadap stabilitas tubuh bendungan urugan terdiri atas analisis stabilitas tubuh bendungan terhadap aliran filtrasi, analisis terhadap stabilitas lereng tubuh bendungan, dan analisis stabilitas tubuh bendungan urugan terhadap sufosi dan piping.

Rumus, syarat, dan metode yang digunakan dalam analisis dimensi tubuh bendungan urugan adalah :

1. Analisis stabilitas lereng terhadap aliran filtrasi

a. Formasi garis depresi
Perhitungan formasi garis depresi menggunakan metode Cassagrande dan rumus yang digunakan adalah :

$y_{o}=\left(h^{2}+d^{2}\right)^{1 / 2}-d$

dengan $\mathrm{y}_{\mathrm{o}}=$ ordinat $(\mathrm{m}), \mathrm{h}=$ jarak vertikal $(\mathrm{m})$, dan $\mathrm{d}=$ jarak horisontal (m) (Sosrodarsono dan Takeda, 2002).

b. Jaringan trayektori aliran filtrasi (seepage flow-net)

Jaringan trayektori digambar menggunakan metode grafis Forchheimer (Sosrodarsono dan Takeda, 2002).

c. Kapasitas aliran filtrasi

$Q_{f}=\left(\frac{N_{f}}{N_{p}}\right) x k \times H \times L$

dengan $\mathrm{Q}_{\mathrm{f}}=$ kapasitas aliran filtrasi $\left(\mathrm{m}^{3} / \mathrm{det}\right), \mathrm{N}_{\mathrm{f}}=$ angka pembagi dari garis trayektori aliran filtrasi, $\mathrm{N}_{\mathrm{p}}=$ angka pembagi dari garis equipotensial, $\mathrm{k}=$ koefisien filtrasi, $\mathrm{H}=$ tinggi tekanan air total $(\mathrm{m})$, dan $\mathrm{L}=$ panjang profil melintang tubuh bendungan $(\mathrm{m})$, dengan syarat $\mathrm{Q}_{\mathrm{f}}<2 \% \mathrm{x}$ Q $\mathrm{Q}_{\text {inflowmax }}$ (Sosrodarsono dan Takeda, 2002).

2. Analisis stabilitas longsor pada lereng tubuh bendungan

Analisis stabilitas longsor pada lereng tubuh bendungan dihitung menggunakan metode Bishop dengan syarat $F_{k} \geq 1,2$ dan rumus yang digunakan adalah :

$$
\begin{aligned}
F_{k}= & \frac{1}{\sum W \times \sin \alpha} \sum\left[c^{\prime} \times b+((W-\right. \\
& \left.(u \times b)) \tan \emptyset) \times \frac{\sec \alpha}{1+\frac{\tan \phi^{\prime} \times \tan \alpha}{F_{k}}}\right]
\end{aligned}
$$

dengan $F_{k}=$ faktor keamanan, $\mathrm{W}=$ berat segmen tanah (ton), $\mathrm{c}^{\prime}=$ kohesi tanah $\left(\right.$ ton $\left./ \mathrm{m}^{2}\right), \mathrm{b}=$ lebar segmen tanah $(\mathrm{m}), \mathrm{u}=$ tegangan air pori $\left(\right.$ ton $\left./ \mathrm{m}^{2}\right), \varnothing=$ sudut geser dalam tanah $\left({ }^{\circ}\right)$, dan $\alpha=$ sudut antara garis vertikal dan jari-jari $\mathrm{R}\left({ }^{\circ}\right.$ ) (Soedarmo dan Purnomo, 1997).

3. Analisis stabilitas terhadap boiling dan piping

$v=k x i$
$c=\sqrt{\frac{w_{1} \times g}{F x \gamma_{w}}}$

Syarat keamanan terhadap boiling dan piping adalah $\mathrm{v}<\mathrm{c}$, dengan $\mathrm{v}=$ kecepatan aliran filtrasi pada bidang keluarnya $(\mathrm{m} / \mathrm{det}), \mathrm{k}=$ koefisien filtrasi, $\mathrm{i}=$ gradient debit, $\mathrm{w}_{1}=$ berat butiran bahan dalam air 
$\left(\right.$ ton $\left./ \mathrm{m}^{3}\right), \mathrm{g}=$ percepatan gravitasi $\left(\mathrm{m} / \mathrm{det}^{2}\right)$, $\mathrm{F}=$ luas permukaan yang menampung aliran filtrasi $\left(\mathrm{m}^{2}\right)$, dan $\gamma_{\mathrm{w}}=$ berat isi air $\left(\right.$ ton $/ \mathrm{m}^{3}$ ) (Sosrodarsono dan Takeda, 2002).

\section{METODE PENELITIAN}

\section{Lokasi Penelitian}

Lokasi penelitian adalah lokasi rencana bendungan urugan Beringin Sila yang berada di Sungai Utan, Desa Tengah Kecamatan Utan Kabupaten Sumbawa Provinsi Nusa Tenggara Barat dengan koordinat lokasi pada $8^{\circ} 27^{\prime} 28,85^{\prime \prime}$ LS dan $117^{\circ} 7^{\prime} 37,36^{\prime \prime}$ BT.

\section{Data Perencanaan}

Data perencanaan yang digunakan dalam analisis dan perhitungan adalah berupa data sekunder yang terdiri dari data topografi, data hidrologi, data geologi teknik, dan data mekanika tanah.

\section{Tahapan Analisis dan Perhitungan}

Tahapan analisis dan perhitungan yang digunakan dalam perencanaan tubuh bendungan urugan adalah :

1. Menghitung kebutuhan air dan tampungan bendungan.

2. Menghitung penelusuran banjir (menggunakan metode penelusuran banjir dalam waduk).

3. Menentukan dimensi tubuh bendungan urugan.

a. Menghitung tinggi jagaan (dengan perhitungan tinggi ombak akibat tiupan angin menggunakan metode SMB).

b. Menghitung tinggi bendungan.

c. Menghitung lebar mercu bendungan.

d. Menentukan panjang bendungan.

e. Menentukan kemiringan lereng hulu dan hilir tubuh bendungan dengan syarat $F_{\mathrm{s}} \geq$ 1,1 .

f. Menentukan jenis pelindung lereng hulu dan lereng hilir pada tubuh bendungan.

g. Menentukan jenis pondasi bendungan.

$\mathrm{h}$. Menentukan jenis drainase bendungan.

4. Menghitung analisis stabilitas tubuh bendungan urugan.

a. Stabilitas lereng terhadap aliran filtrasi.

1.) Formasi garis depresi dihitung menggunakan metode Cassagrande.

2.) Jaringan trayektori digambar menggunakan metode grafis Forchheimer.
3.) Kapasitas aliran filtrasi.

b. Stabilitas longsor pada lereng tubuh bendungan dihitung menggunakan metode Bishop dengan syarat $F_{\mathrm{s}} \geq 1,2$.

c. Stabilitas terhadap boiling dan piping.

\section{HASIL DAN PEMBAHASAN}

\section{Kebutuhan Air dan Volume Tampungan}

Kebutuhan air irigasi dan air baku maksimal masing-masing sebesar 55.987.200 $\mathrm{m}^{3}$ dan $2.680 .560 \mathrm{~m}^{3}$, sehingga total kebutuhan air rencana adalah $58.667 .760 \mathrm{~m}^{3}$. Selain merencanakan kebutuhan air, juga direncanakan volume tampungan mati maksimal yaitu sebesar $4.200 .000 \mathrm{~m}^{3}$ dengan elevasi permukaan tampungan mati berada pada elevas $+104,50$.

Berdasarkan data-data tersebut dapat ditentukan elevasi dan volume tampungan untuk M.A.R dan M.A.N. M.A.R direncanakan dengan ketinggian minimal $50 \mathrm{~cm}$, sehingga diketahui elevasi rencana M.A. adalah +105 dengan volume tampungan M.A.R adalah 4.571.428,57 $\mathrm{m}^{3}$. M.A.N direncanakan berdasarkan volume tampungan normal sebesar $64.042 .857,14 \mathrm{~m}^{3}$ pada elevasi +161 .

\section{Penelusuran Banjir}

Penelusuran banjir yang dilakukan pada bangunan pelimpah berpengaruh pada tubuh bendungan urugan dalam bentuk ketinggian muka air banjir dan digunakan untuk menentukan dimensi tinggi bendungan. Berdasarkan hasil perhitungan penelusuran banjir dalam waduk diperoleh debit outflow rencana dengan kala ulang 1.000 tahunan $\left(\mathrm{Q}_{1.000}\right)$ adalah sebesar $291,63 \mathrm{~m}^{3} / \mathrm{det}$, tinggi air di atas ambang pelimpah adalah 1,61 meter, dan elevasi muka air banjir adalah $+162,61$.

\section{Dimensi Tubuh Bendungan Urugan}

Tubuh bendungan urugan direncanakan berupa bendungan urugan batu dengan inti kedap air tegak dan perhitungan dimensi tubuh bendungan urugan dapat dilakukan berdasarkan data hasil perhitungan terhadap tampungan bendungan, muka air normal, muka air banjir, dan tampungan mati.

\section{Tinggi jagaan}

Tinggi jagaan tubuh bendungan dapat diperoleh dengan memilih nilai terbesar dari kombinasi hasil perhitungan terhadap tinggi 
kemungkinan kenaikan permukaan air waduk yang terjadi akibat timbulnya banjir abnormal $(\Delta \mathrm{h})=0,10$ meter, tinggi jangkauan ombak yang disebabkan oleh angin $\left(h_{w}\right)=0,53$ meter, tinggi ombak akibat gempa $\left(\mathrm{h}_{\mathrm{e}}\right)=3,41$ meter, tinggi kemungkinan kenaikan permukaan air waduk apabila terjadi kemacetan pada pintu bangunan pelimpah $\left(h_{a}\right)=0,00$ meter, dan tinggi tambahan $\left(\mathrm{h}_{\mathrm{i}}\right)=1$ meter. Berdasarkan hasil kombinasi perhitungan, nilai terbesar tinggi jagaan adalah 3,24 meter > nilai tinggi jagaan standar untuk bendungan dengan tinggi antara 50-100 meter yaitu 3 meter, sehingga tinggi jagaan yang digunakan adalah 3,24 meter.

2. Tinggi bendungan

Dengan elevasi dasar bendungan rencana pada +80 , elevasi M.A.B pada $+162,61$ dan tinggi jagaan sebesar 3,24 meter, maka tinggi bendungan rencana adalah 85,84 meter. Namun dengan mempertimbangkan terjadinya penurunan tubuh bendungan dan adanya proses konsolidasi, maka ditambahkan faktor besar penimbunan ekstra (extra banking) sebesar 1\% dari tinggi bendungan yaitu sebesar 0,86 meter, sehingga total tinggi bendungan rencana adalah 87 meter dan elevasi mercu bendungan pada +167 .

3. Lebar mercu bendungan

Lebar mercu bendungan hasil perhitungan adalah 13 meter.

4. Panjang bendungan

Panjang bendungan ditentukan berdasarkan tinggi bendungan dan topografi bendungan, sehingga diperoleh panjang bendungan adalah 800,93 meter.

5. Kemiringan lereng hulu dan kemiringan lereng hilir

Kemiringan lereng hulu dan kemiringan lereng hilir tubuh bendungan direncanakan sebesar $1 \mathrm{~V}: 4 \mathrm{H}$ dan $1 \mathrm{~V}: 3 \mathrm{H}$ dengan nilai faktor keamanan $\left(\mathrm{F}_{\mathrm{s}}\right)$ masing-masing sebesar $1,62>1,1$ (aman) dan 1,23>1,1 (aman).

6. Pelindung lereng tubuh bendungan

Pelindung lereng tubuh bendungan direncanakan berupa hamparan batu (riprap) di sisi hulu dan hilirnya. Ketebalan lapisan riprap dapat ditentukan berdasarkan nilai $\mathrm{h}_{\mathrm{w}}$ pada perhitungan tinggi jagaan, yaitu 0,53 meter.

Dengan nilai $h_{w}$ sebesar 0,53 meter, maka diperoleh diameter rata-rata batu pelindung $25 \mathrm{~cm}$, ketebalan minimum hamparan batu pelindung $30 \mathrm{~cm}$ dan direncanakanan setebal $100 \mathrm{~cm}$, serta ketebalan minimum lapisan filter sebesar $15 \mathrm{~cm}$ dan direncanakan tebal lapisan filter kasar sebesar $500 \mathrm{~cm}$, dan ketebalan lapisan filter halus sebesar 800 $\mathrm{cm}$.

\section{Pondasi bendungan}

Pondasi bendungan direncanakan sesuai dengan keadaan geologi as bendungan. Berdasarkan kondisi geologi pada as lokasi bendungan, maka direncanakan formasi batuan yang digunakan sebagai pondasi adalah berupa pondasi alluvial dengan kualifikasi material berupa material lepas berukuran bongkah, kerakal, kerikil, pasir, lanau, lempung sebagai endapan sungai.

8. Drainase bendungan

Drainase bendungan direncanakan berupa drainase horizontal pada bagian bawah bendungan atau disebut dengan drainase alas. Drainase alas digunakan pada bendungan dengan zona kedap air yang lebar karena efek peningkatan kekedapan airnya yang cukup baik. Drainase alas horizontal direncanakan menggunakan material filter halus. Kedalaman drainase alas sebesar 2 meter dan panjang 240 meter.

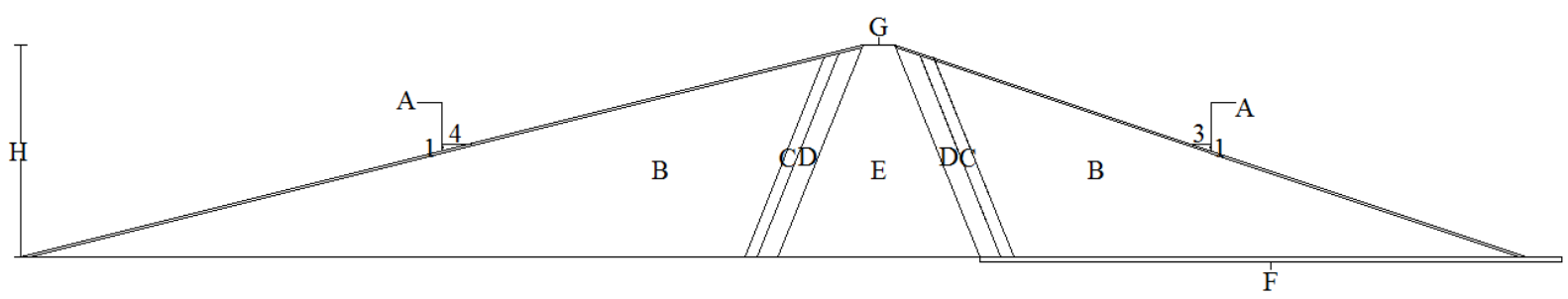

Gambar 1. Penampang melintang bendungan urugan rencana 
Keterangan :
$\mathrm{A}=$ Riprap
$\mathrm{E} \quad=$ Inti lempung
$\mathrm{B}=\mathrm{Batu}$
$\mathrm{F}=$ Drainase
horizontal
$\mathrm{C}=$ Filter kasar
$\mathrm{D}=$ Filter halus
$\mathrm{G} \quad=$ Mercu bendungan
$\mathrm{H}$ = Tinggi
Bendungan

\section{Stabilitas Tubuh Bendungan Urugan}

1. Stabilitas terhadap aliran filtrasi a. Formasi garis depresi

Formasi garis depresi dihitung menggunakan metode Cassagrande untuk mendapatkan koordinat parabola dasar pembentuk garis depresi. Titiktitik koordinat parabola tersebut dihubungkan dan digabungkan dengan skema penampang melintang bendungan urugan rencana sehingga membentuk skema formasi garis depresi pada bendungan dengan inti vertikal.

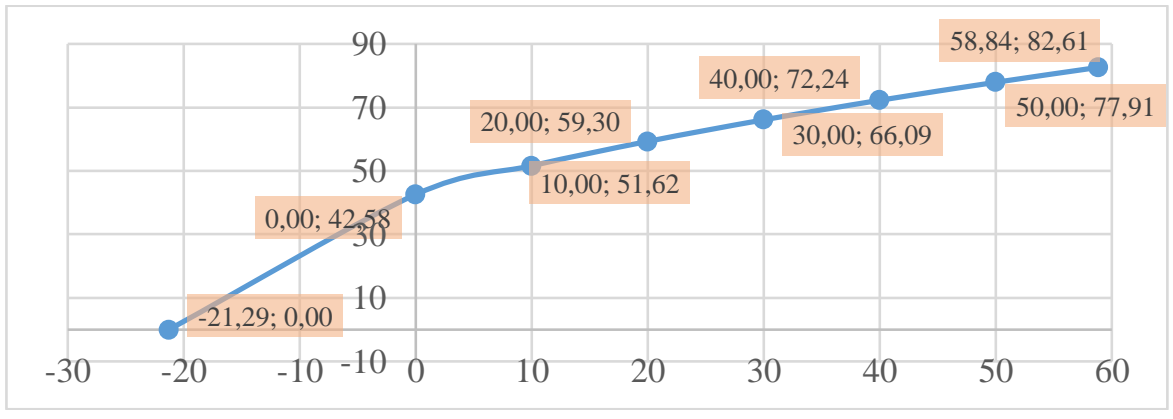

Gambar 2. Koordinat parabola

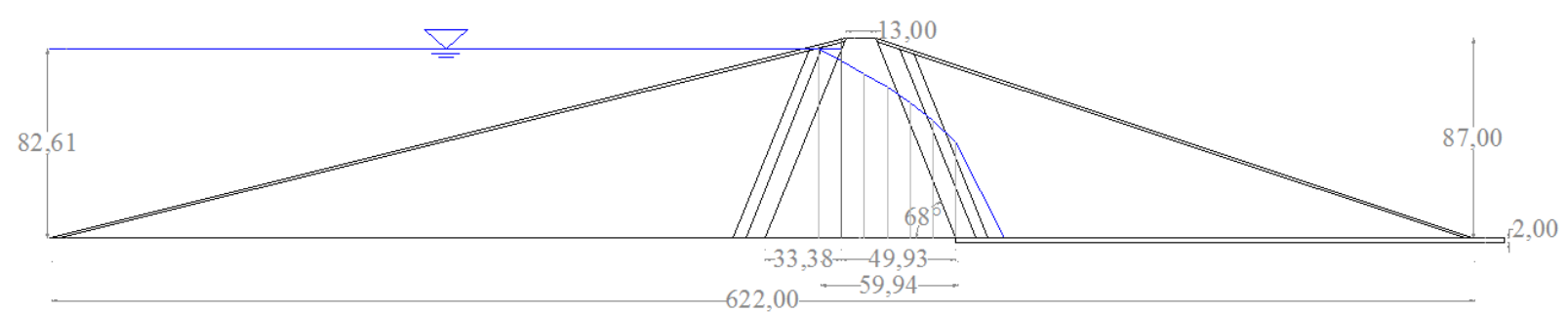

Gambar 3. Skema formasi garis depresi pada bendungan inti vertikal

b. Jaringan trayektori Jaringan trayektori pada tubuh bendungan digambar dengan metode grafis Forchheimer.
Jaringan trayektori rencana terdiri dari garis trayektori $\left(\mathrm{N}_{\mathrm{f}}\right)$ sebanyak 10 garis, garis equipotensial $\left(\mathrm{N}_{\mathrm{p}}\right)$ sebanyak 11 garis.

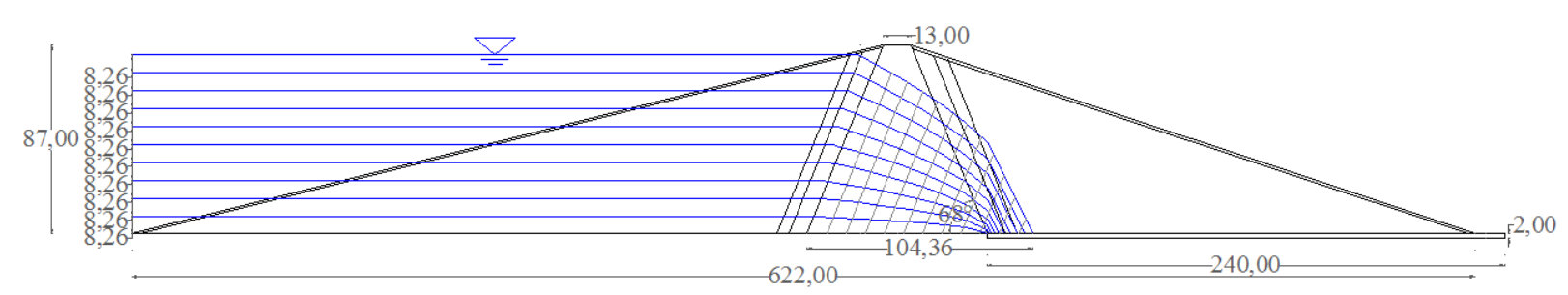

Gambar 4. Jaringan trayektori aliran filtrasi

c. Kapasitas aliran filtrasi

Kapasitas aliran filtrasi pada tubuh bendungan dihitung berdasarkan jaringan trayektori aliran filtrasi, sehingga diperoleh kapasitas aliran filtrasi $\left(\mathrm{Q}_{\mathrm{f}}\right)$ sebesar $11,88 \times 10^{-3} \mathrm{~m}^{3} / \mathrm{det}<$
$2 \% \times$ Q Qinflow maks yaitu $11,80 \mathrm{~m}^{3} / \mathrm{det}$ (aman).

2. Stabilitas longsor pada lereng tubuh bendungan

Stabilitas longsor pada lereng tubuh bendungan dihitung menggunakan metode 
Bishop dengan syarat faktor keamanan $\left(\mathrm{F}_{\mathrm{s}}\right)>$ 1,2. Stabilitas longsor ditinjau dalam tiga kondisi, yaitu pada saat bendungan baru selesai dibangun (tinjau lereng hulu dan lereng hilir), saat bendungan mencapai elevasi penuh (tinjau lereng hulu), pada saat bendungan mengalami penurunan air mendadak (rapid drawdown) (tinjau lereng hilir).

a. Pada saat bendungan baru selesai dibangun (tinjau lereng hulu dan lereng hilir)
Stabilitas longsor pada lereng tubuh bendungan urugan pada kondisi bendungan baru selesai dibangun yang ditinjau pada lereng hulu diperoleh angka keamanan $\left(\mathrm{F}_{\mathrm{s}}\right)$ sebesar 4,34>1,2 dan yang ditinjau pada lereng hilir diperoleh angka keamanan $\left(\mathrm{F}_{\mathrm{s}}\right)$ sebesar $2,99>1,2$. Angka keamanan yang lebih dari atau sama dengan 1,2 masuk dalam kategori aman.

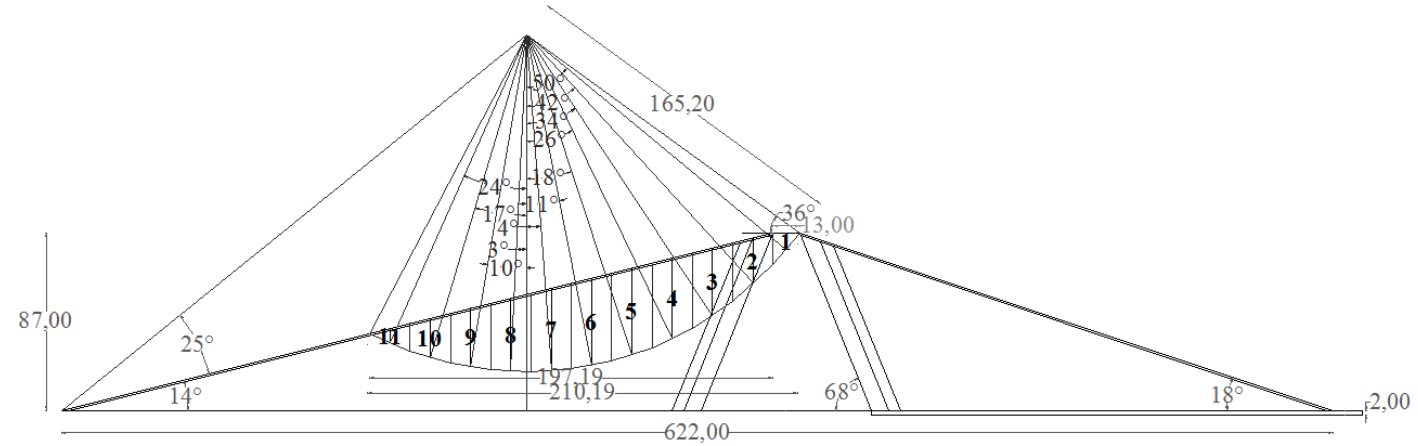

Gambar 5. Sketsa stabilitas longsor pada lereng bendungan saat bendungan baru selesai dibangun tinjau lereng hulu

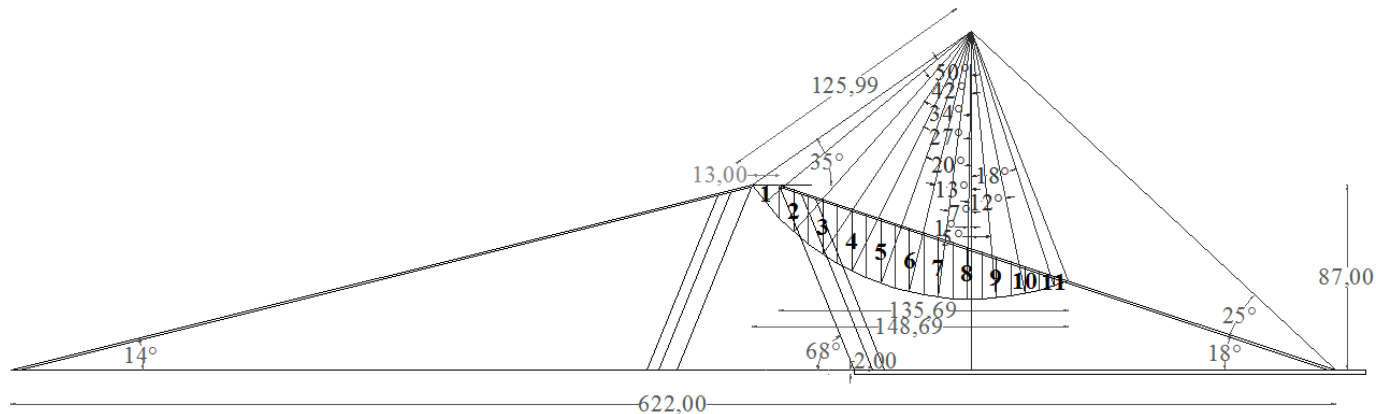

Gambar 6. Sketsa stabilitas longsor pada lereng bendungan saat bendungan baru selesai dibangun tinjau lereng hilir

b. Pada saat muka air bendungan mencapai elevasi penuh (tinjau lereng hilir) Stabilitas longsor pada lereng tubuh bendungan urugan pada kondisi muka air mencapai elevasi muka air penuh yang ditinjau pada lereng hulu diperoleh angka keamanan $\left(\mathrm{F}_{\mathrm{s}}\right)$ sebesar 2,13>1,2. Angka keamanan lebih dari atau sama dengan 1,2 masuk dalam kategori aman.

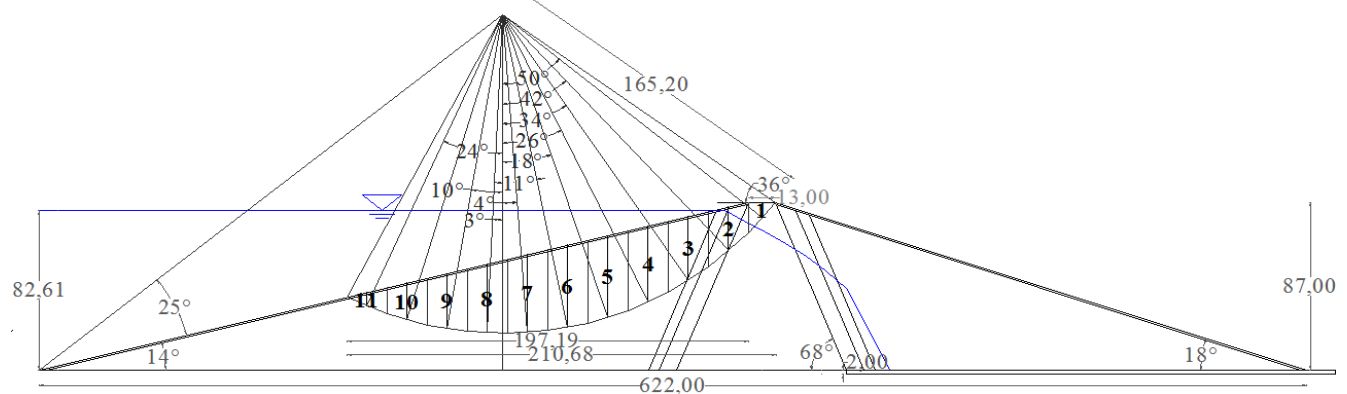

Gambar 7. Sketsa stabilitas longsor pada lereng bendungan saat bendungan mencapai elevasi muka air penuh 
c. Pada saat bendungan mengalami penurunan air mendadak (tinjau lereng hulu)

Stabilitas longsor pada lereng tubuh bendungan urugan pada kondisi muka air mencapai elevasi muka air penuh yang ditinjau pada lereng hulu diperoleh angka keamanan $\left(\mathrm{F}_{\mathrm{s}}\right)$ sebesar 3,82 > 1,2. Angka keamanan lebih dari atau sama dengan 1,2 masuk dalam kategori aman.

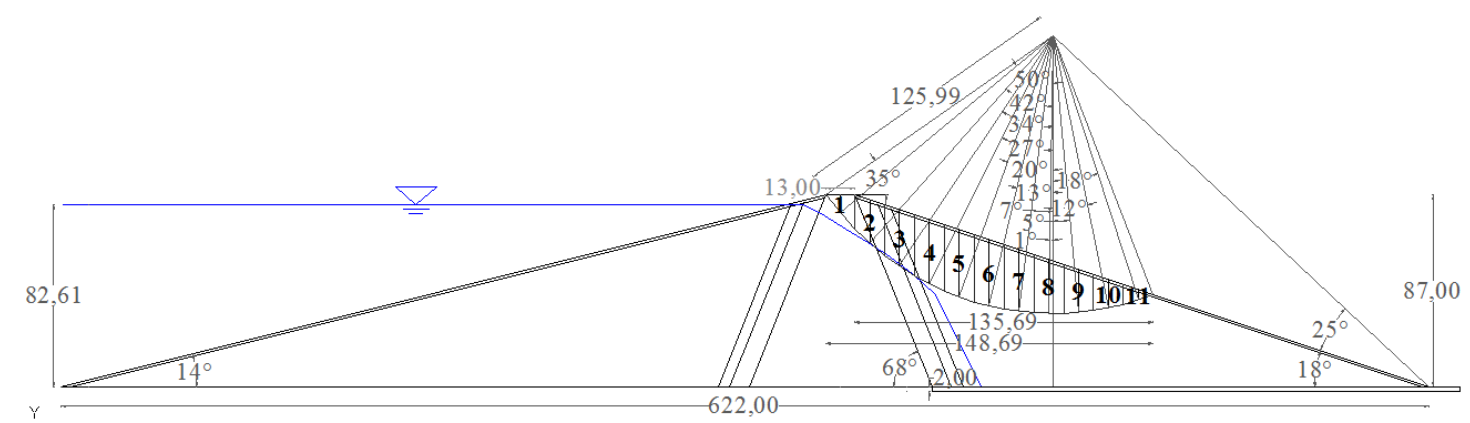

Gaumbar 8. Sketsa stabilitas longsor pada lereng bendungan saat bendungan mengalami penurunan air mendadak

3. Stabilitas terhadap boiling dan piping

Agar tubuh bendungan aman terhadap boiling dan piping harus memenuhi syarat yaitu kecepatan rembesan (v) < kecepatan kritis (c), dan hasil perhitungan kecepatan rembesan (v) adalah $6,44 \times 10^{-5} \mathrm{~m} / \mathrm{det}<$ kecepatan kritis (c) 0,06 $\mathrm{m} / \mathrm{det}$, maka stabilitas tubuh bendungan terhadap boiling dan piping dinyatakan aman.

\section{PENUTUP}

\section{Kesimpulan}

Bendungan urugan direncanakan dengan tipe urugan batu dengan inti kedap air tegak. Tujuan pembangunan adalah untuk memenuhi kebutuhan air irigasi dan air baku, sehingga berdasarkan hasil analisis diperoleh :

1. Dimensi tubuh bendungan

Tinggi bendungan 87 meter, lebar mercu bendungan 13 meter, panjang bendungan 800,93 meter, kemiringan lereng hulu $1 \mathrm{~V}: 4 \mathrm{H}$, kemiringan lereng hilir $1 \mathrm{~V}: 3 \mathrm{H}$, tebal riprap $100 \mathrm{~cm}$, tebal lapisan filter kasar 500 $\mathrm{cm}$, tebal lapisan filter halus $800 \mathrm{~cm}$, serta drainase horizontal dengan kedalaman 2 meter dan panjang 240 meter.

2. Stabilitas tubuh bendungan

Stabilitas pada tubuh bendungan ditinjau terhadap terhadap aliran filtrasi dengan kapasitas aliran $\left(\mathrm{Q}_{\mathrm{f}}\right) 11,88 \times 10^{-3} \mathrm{~m}^{3} / \mathrm{det}<$

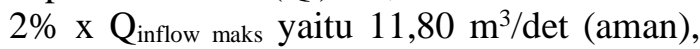
stabilitas longsor pada lereng tubuh bendungan yang dihitung berdasarkan berbagai kondisi, antara lain pada saat bendungan baru selesai dibangun sisi hulu dengan angka keamanan $\left(\mathrm{F}_{\mathrm{s}}\right)$ 4,34 > 1,2 (aman), pada saat bendungan baru selesai dibangun sisi hilir dengan angka keamanan ( $F_{\mathrm{s}}$ ) 2,99 > 1,2 (aman), pada saat bendungan mencapai elevasi penuh (tinjau lereng hilir) dengan angka keamanan $\left(\mathrm{F}_{\mathrm{s}}\right) 2,13>1,2$ (aman), pada saat bendungan mengalami penurunan air mendadak (tinjau lereng hulu) dengan angka keamanan $\left(\mathrm{F}_{\mathrm{s}}\right)$ 3,82>1,2 (aman), serta stabilitas terhadap boiling dan piping dengan kecepatan rembesan (v) adalah $6,44 \times 10^{-5} \mathrm{~m} / \mathrm{det}<$ kecepatan kritis (c) $0,06 \mathrm{~m} / \mathrm{det}$ (aman).

\section{Saran}

Mengingat terdapat keterbatasan data perencanaan serta banyak metode yang dapat digunakan dalam analisis dimensi tubuh bendungan dan stabilitas tubuh bendungan, maka diperlukan penelitian lanjutan sebagai pembanding dengan tujuan untuk mendapatkan desain alternatif lain yang lebih efektif dan efisien.

\section{DAFTAR PUSTAKA}

Anonim. (2003). Pedoman Kriteria Umum Desain Bendungan. Departemen Pemukiman dan Prasarana Wilayah Direktorat Jenderal Sumber Daya Air Komisi Keamanan Bendungan.

Masrevaniah, A. (2010). Konstruksi Bendungan Urugan Volume I. CV. Asrori Malang, Malang.

Soedarmo, G.D., dan Purnomo, S.J.E. (1997). Mekanika Tanah 2. Kanisius, Malang. 
Soedibyo. (2003). Teknik Bendungan. Pradnya Paramita, Jakarta.

Soemarno, C.D. (1987). Hidrologi Teknik.

Usaha Offset Printing, Surabaya. 